\title{
Identifikasi Penyebaran Zona Korosi dan Menentukan Tempat Pemasangan Anoda untuk Proteksi Katodik pada Lapangan Unit 7 \& 8 PT. IPMOMI menggunakan Metode Resistivitas 2D Konfigurasi Wenner-Alpha
}

\author{
Yuri Syahwirawan, Anik Hilyah, dan Widya Utama \\ Departemen Teknik Geofisika, Fakultas Teknik Sipil dan Perencanaan, Institut Teknologi Sepuluh Nopember (ITS) \\ e-mail: anik.hilyah@gmail.com
}

\begin{abstract}
Abstrak-Telah dilakukan penelitian tentang zonasi lingkungan korosif dan pencarian lokasi pemasangan anoda untuk proteksi katodik. Korosi merupakan proses perusakan pada permukaan logam akibat pengaruh lingkungan yang korosif. Pada PT. IPMOMI terdapat jaringan pipa transmisi yang dapat mengalami korosi dan mengakibatkan kerugian besar bagi perusahaan. Lokasi pemasangan jaringan pipa tersebut merupakan tanah reklamasi (tanah urukan) yang ditimbun di bibir pantai sehingga pengaruh air laut menjadikan potensi korosi sangat tinggi. Untuk mengetahui penyebaran lingkungan korosi dan tempat pemasangan anoda yang efektif dan efisien untuk proteksi katodik maka dilakukan penelitian geolistrik menggunakan metode resistivitas 2D dengan konfigurasi Wenner Alpha. Hasil pengukuran didapatkan pada kedalaman 0 meter sampai 4 meter didominasi oleh zona korosivitas sangat rendah dengan nilai resistivitas lebih dari $50 \mathrm{Ohm}-\mathrm{m}$, sedangkan pada kedalaman lebih dari 4 meter didominasi oleh zona korosivitas sangat tinggi dengan nilai resistivitas dibawah $7 \mathrm{Ohm}-\mathrm{m}$. Lokasi pemasangan anoda adalah pada nilai resistivitas 8 ohm-m hingga 20 ohm-m yaitu pada lintasan 1 diantara bentangan 10 meter sampai 20 meter di kedalaman \pm 3 meter, pada lintasan 3 diantara bentangan 20 meter sampai 28 meter di kedalaman \pm 3 meter, dan pada lintasan 5 diantara bentangan 20 meter sampai 25 meter dikedalaman \pm 3 meter.
\end{abstract}

Kata Kunci-Anoda, Korosi, Resistivitas 2D, Wenner-Alpha.

\section{PENDAHULUAN}

L OGAM sebagai bahan baku utama suatu industri memiliki $L_{k}$ arakteristik tersendiri dalam penanganan atau mitigasi resikonya. Salah satu resiko yang perlu mendapat perhatian yaitu pengendalian terhadap korosi. Korosi merupakan penyebab vital dari kerugian dan kegagalan material industri pembangkit listrik salah satunya di PT. IPMOMI. Salah satu aset penting dalam industri di PLTU adalah penyaluran air laut menuju sistem pendingin utama. Maka digunakan sistem jaringan pipa atau pipeline sebagai jaur transmisi dan distribusi paling aman, mudah, dan efisien yang secara ironi menjadi pemilik persentase tertinggi pada industri tersebut yang diakibatkan karena korosi. Jaringan Pipa (pipeline) terdiri dari flowline yang menyalurkan air laut yang menuju sistem pendingin. Jaringan-jaringan pipa tersebut pada umumnya terbuat dari baja karbon atau baja paduan khusus. Resiko terjadinya korosi baik dari dalam maupun luar bagian pipa merupakan suatu masalah yang perlu ditangani [1].

Sebagai langkah awal dalam menangani masalah korosi tersebut kita perlu mengenali lingkungan korosi. Salah satu upaya yang dapat dilakukan adalah dengan melihat nilai resistivitas lingkungan sehingga dapat diketahui besar potensi korosi yang dapat ditimbulkan. Metode yang dapat digunakan adalah metode geolistrik. Berdasarkan penampang resistivitas (tahanan jenis) dapat diindikasikan potensi korosi yang dapat ditimbulkan yaitu semakin tinggi nilai resistivitas lingkungan menunjukan semakin rendah sifat korosivitas dari lingkungan tersebut. Nilai resistivitas juga dapat digunakan untuk menentukan lokasi pemasangan anoda pada proteksi katodik. Perlunya survei nilai resistivitas untuk lokasi pemasangan anoda adalah untuk mencari lokasi dengan nilai resistivitas kecil. Nilai resistivitas yang kecil diperlukan untuk tempat pemasangan anoda agar proses pelepasan elekton dari anoda ke katoda lebih mudah dan cepat sehingga proteksi katodik dapat berjalan optimal.

Lokasi penelitian merupakan tanah urukan atau tanah reklamasi mengakibatkan litologi daerah penelitian telah berubah, sehingga metode yang dipilih adalah metode geolistrik resistivitas 2D. Berdasarkan penelitian yang dilakukan oleh Putra [2] metode resistivitas 2D dengan konfigurasi Wenner Alpha sangat baik dalam mendeteksi lingkungan yang korosif yang ditandai dengan nilai resistivitas kecil karena konfigurasi Wenner Alpha yang sensitif terhadap perubahan lateral dan cocok sekali untuk penelitian dangkal mencari penyebaran lingkungan korosif. Selain itu biaya survei murah, peralatan relatif kecil dan ringan, serta waktu pengukuran yang relatif cepat. Hasil dari penelitian ini dapat menjadi acuan bagi perusahaan untuk perancangan pemasangan pipa bawah permukaan, perancarangan proteksi katodik, mendeteksi apabila terjadi kebocoran pipa adalah lebih fokus pada lingkungan dengan sifat korosif yang tinggi serta tempat pemasangan anoda proteksi katodik yang tepat. 


\section{TINJAUAN PUSTAKA}

Berdasarkan penelitian yang dilakukan oleh Putra [2] metode resistivitas 2D dengan konfigurasi Wenner Alpha sangat baik dalam mendeteksi lingkungan yang korosif yang ditandai dengan nilai resistivitas kecil karena konfigurasi Wenner Alpha yang sensitif terhadap perubahan lateral dan cocok sekali untuk penelitian dangkal mencari penyebaran lingkungan korosif. Konfigurasi Wenner Alpha memiliki konfigurasi yang sama, tetapi jarak antar elektrodanya sama. Jarak antar elektroda arus adalah sama, seperti terlihat dalam Gambar 1.

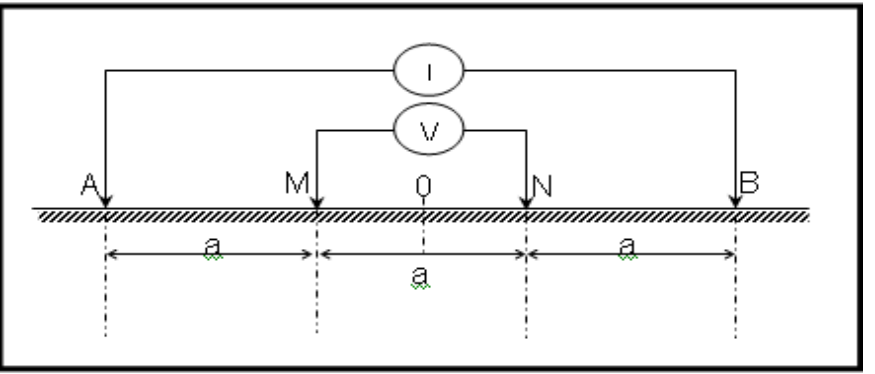

Gambar 1. Susunan elektroda Konfigurasi Wenner Alpha [3]

Dalam konfigurasi ini diketahui bahwa $\mathrm{AM}=\mathrm{MN}=\mathrm{BN}=\mathrm{a}$, sehingga harga faktor geometri dan resistivitas semunya menjadi :

$$
\begin{gathered}
K_{w}=2 \pi a \\
\rho_{a W}=2 \pi a \frac{\Delta V}{I}
\end{gathered}
$$

Tabel 1 merupakan table yang menjadi referensi dalam penzonaan sifat korosivitas daerah penelitian.

Tabel 1.

Resistivitas Tanah dan Pendugaan Sifat Korosi Tanah [3]

\begin{tabular}{cc}
\hline \hline Resistivitas Tanah $(\Omega \mathrm{m})$ & Pendugaan Sifat Korosi \\
\hline$<7$ & Sangat tinggi \\
$7-20$ & Tinggi \\
$20-50$ & Sedang \\
$50-100$ & Rendah \\
$>100$ & Sangat rendah \\
\hline \hline
\end{tabular}

\section{METODOLOGI PENELITIAN}

Akuisisi data Resistivitas dilapangan telah dilaksanakan pada tanggal 3 sampai tanggal 16 Mei 2017 di lapangan unit 7 dan unit 8 PT.IPMOMI kecamatan Paiton kabupaten Probolinggo.

Hal yang pertama dilakukan adalah melakukan survei lokasi kemudian mencocokan jenis batuan yang ada dilokasi dengan jenis batuan berdasaarkan peta geologi. Kemudian dilakukan pemilihan desain akuisisi dalam pengambilan data.

Metode yang dipilih adalah metode risistivitas 2D dengan konfigurasi Wenner Alpha. Kemudian dilakukan pembentangan meteran, pada lintasan 1 dan 2 panjang lintasan adalah 72 meter dengan jarak terkecil antar elektodanya adalah 1,5 meter. Lintasan 3 dan 4 dengan panjang lintasan 32 meter dengan jarak terkecil antar elektrodanya adalah 1 meter dan lintasan 5 dengan jarak terkecil antar elektrodanya adalah 1,5 meter. Sebelum dilakukan pengambilan data dilakukan pengecekan alat pada resistivity meter dan aki. Dilakukan pengisian ulang aki ketika nilai beda tegangannya $<12$ volt.
Setelah sampai dilokasi, dilakuakan penancapan elektroda dan dihubungkan dengan alat resistivity meter. Elektroda di tancapkan sepanjang lintasan sesuai jarak antar elektoda yang telah ditentukan. Setelah elektroda terpasang dan telah terhubung ke alat resistivitimeter makan dilakukan connection test. Setelah persiapan alat telah sempurna maka dimulai pengambilan data, dari pengambilan data akan mendapatkan nilai arus ( $I$ ) dan tegangan $(v)$ yang kemudian diolah menggunakan excel disimpan dalam format dat kemudian diolah menggunakan res2Dinv.

\section{HASIL DAN DISKUSI}

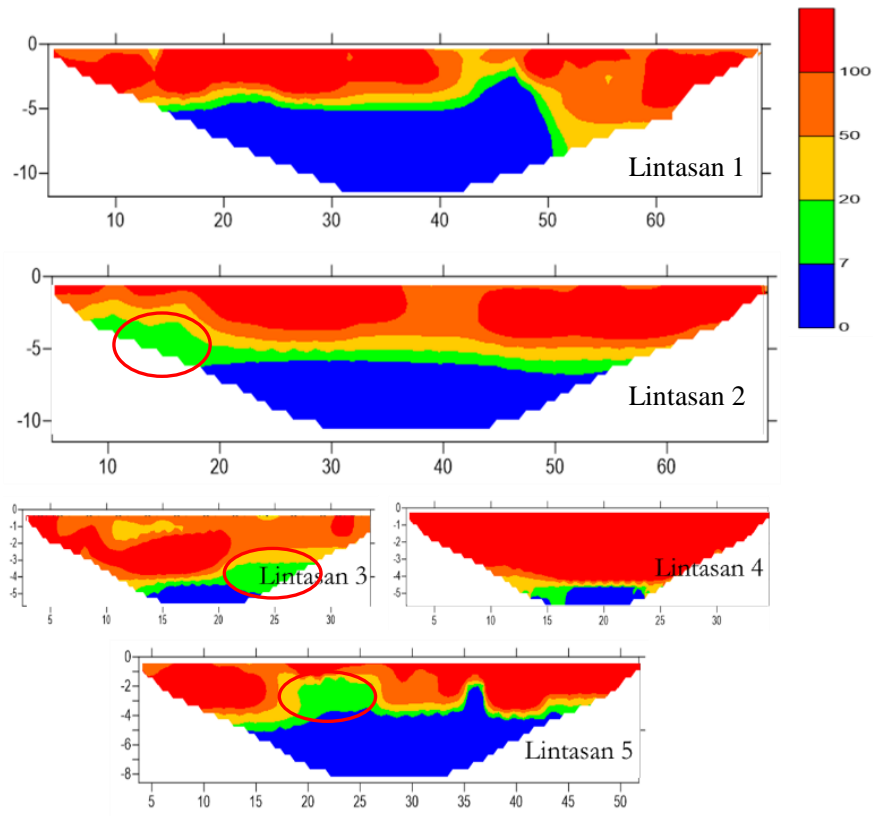

Gambar 2. Zona korosivitas hasil penelitian

Daerah penelitian merupakan hasil reklamasi pantai dengan menggunakan tanah dan batuan untuk reklamasi yang didapatkan dari percampuran Aluvium (Qal) dan Formasi Batuan Gunungapi Ringgit (QTy) pada tahun pembangunan sehingga dalam interpretasi data hasil pengolahan data geolistrik digunakan parameter dari Qal dan QTy. Lapisan Aluvium (Qal) berisikan kerakal, kerikil, pasir, lanau dan lempung sebagai endapan sungai dan pantai. Formasi Batuan Gunungapi Ringgit (QTy) berisikan Lava, breksi gunungapi, tuf dan sisipan batupasir tufan.

Gambar 2 merupakan penampang resistivitas yang telah dizonasi sesuai dugaan sifat korosinya berdasarkan tabel 3 . Secara keseluruhan daerah penelitian ini di dominasi oleh zona korosi sangat rendah dan rendah yang tersebar pada kedalaman 0 sampai $\pm 4 \mathrm{~m}$ yaitu pada litologi pasir tuffan, kerikil, lempung terdapat kerakal basalt dan sangat tinggi yang tersebar pada kedalaman lebih dari 4 meter yaitu pada litologi pasir tuffan, kerikil dan kerakal basalt. Bila diperhatikan penampang resistivitas sebagian besar memperlihatkan kenaikan skala resistivitas dari rendah ketinggi dari bawah keatas, hal ini merupakan pengaruh dari instrusi air laut karena sifat fluida yang merembas dari bawah keatas sehingga semakin keatas kandungan fluida semakin sedikit, 
Oleh karena bagian atasnya merupakan tanah urukan bekas reklamasi menyebabkan range atau skala resistivitas tanah bagian atas dan bawahnya jauh berbeda. Hal ini di sebabkan oleh material yang di timbunkan di daerah tersebut berbedabeda yang tidak tersebar merata dengan kompaksi yang berbeda.

Anoda merupakan besi yang di jadikan tumbal pada proteksi katodik. Dengan proteksi katodik akan menjadikan besi pipa yang diproteksi sebagai katoda, sehingga korosi yang terjadi adalah pada besi anoda. Dengan adanya proteksi katodik besi yang tanam akan tahan lebih lama sehingga dapat mencegah kerugian akibat korosi pada pipa meskipun korosi pada pipa tetap terjadi tetapi dapat ditekan laju korosinya sehingga menjadi sangat kecil.

Lokasi pemasangan anoda adalah pada area yang dilingkari pada gambar 2 yaitu pada nilai resistivitas $8 \mathrm{ohm}-\mathrm{m}$ hingga 20 ohm-m yaitu pada lintasan 2 diantara bentangan 10 meter sampai 20 meter di kedalaman \pm 3 meter, pada lintasan 3 diantara bentangan 20 meter sampai 28 meter di kedalaman \pm 3 meter, dan pada lintasan 5 diantara bentangan 20 meter sampai 25 meter dikedalaman \pm 3 meter.

\section{KESIMPULAN}

\section{A. Simpulan}

Berdasarkan hasil dan pembahasan pada bab sebelumnya, kesimpulan dari penelitian ini adalah sebagai berikut:

1) Pada kedalaman 0 meter sampai 4 meter didominasi oleh zona korosivitas sangat rendah dengan nilai resistivitas lebih dari $50 \mathrm{Ohm}-\mathrm{m}$.
2) Pada kedalaman lebih dari 4 meter didominasi oleh zona korosivitas sangat tinggi dengan nilai resistivitas dibawah 7 Ohm-m.

3) Lokasi pemasangan anoda adalah pada nilai resistivitas $8 \mathrm{ohm}-\mathrm{m}$ hingga $20 \mathrm{ohm}-\mathrm{m}$ yaitu pada lintasan 2 diantara bentangan 10 meter sampai 20 meter di kedalaman \pm 3 meter, pada lintasan 3 diantara bentangan 20 meter sampai 28 meter di kedalaman \pm 3 meter, dan pada lintasan 5 diantara bentangan 20 meter sampai 25 meter dikedalaman \pm 3 meter.

\section{B. Saran}

Saran dari hasil penelitian ini adalah sebagai berikut:

1) Perusahaan PT. IPMOMI hendaknya melakukan pengukuran resistivitas $2 \mathrm{D}$ pada saat air laut pasang sehingga dapat diketahui pengaruh air laut terhadap sifat korosivitas tanah.

2) Tempat pemasangan anoda hendaknya pada tempat yang ditunjukan pada hasil, sesuai kesimpulan

\section{DAFTAR PUSTAKA}

P. S. S. Bernanda, “Analisa Penggunaan Impressed Current Cathodic Protection (ICCP) pada Sistem Pendingin Utama Unit $1 \& 2$ PLTU PAITON," 2012.

A. P. Putra, "Pemodelan Sebaran Air Asam Tambang Menggunakan Metode Geolistrik Tahanan Jenis Konfigurasi Wenner Alpha," Hasanuddin Univ., 2013.

[3] Puslitbang Metalurgi-LIPI, Korosi dan Penanggulangannya. 1987. 